\title{
Estimation of Large Animals Dung for Power Generation - A Case Study of District Bathinda, Punjab
}

\author{
Gagandeep Kaur ${ }^{\mathrm{a}}$, Yadwinder Singh Brar ${ }^{\mathrm{b}}$, D.P.Kothari ${ }^{\mathrm{c}}$ \\ ${ }^{a}$ Punjab Institute of Technology, Kapurthala, PTU Main Campus, Punjab 148106, India \\ ${ }^{b}$ Electrical Engg. Deptt., Guru Nanak Engineering College, Ludhiana, Punjab, India \\ ${ }^{c}$ Director, MVSR Engineering College, Hyderabad, Andhra Pradesh, India
}

\begin{abstract}
Large animals dung based biomass has immense potential in an agricultural state Punjab. The milk production is very important part of an agricultural economy in the Punjab. Dairy farming is an age old subsidiary profession in rural areas of state. This paper presents a case study of Bathinda district of Punjab by collecting the total livestock population and the average production of large animals dung or manure on daily basis. About $13 \%$ of total animal dung in district is used for local level activities and $87 \%$ is considered as surplus animal dung which can be used for production of electrical power. Based on these collections and from the surplus animal dung the energy potential of $1385247 \mathrm{GJ}$ per year has been calculated. It has been estimated that electrical power of 384.8 GWH per year can be produced only from the surplus large animal dung of district Bathinda of Punjab.
\end{abstract}

\section{Introduction}

Biomass energy is an energy produced from an organic matter like agricultural residues, wood and food wastes etc. Since the existence of man it has been an important energy source for household activities in rural areas [1]. In this world there are so many biomass resources available to convert into other usable forms of energy. Punjab is an agricultural rich state and livestock is playing an important and major role in farming like dairy farming. As the livestock is source of income for many small and large farmers in state, the proper disposal of animal dung is also a matter of concern for farmers [2]. The agricultural farmers generally use the some portion of animal dung for fertilizer, for domestic usage and for biogas plants at local level. The rest of it is dumped in storage areas or as lagoons. The appropriate disposal of animal dung is to use it as biomass energy which helps us to reduce energy cost and costs associated with animal dung management [2]. The aggregate analysis of the total large animal dung potential is done for converting dung into an electrical power or domestic renewable fuel livestock source. This paper focuses on the assess ment of animal dung potential in district Bathinda of Punjab to produce electrical energy.

\subsection{Profile of District Bathinda of Punjab State}

The Punjab state is located between $29^{\circ} 33^{\prime}$ to $32^{\circ} 32^{\prime} \mathrm{N}$ latitude and $73^{\circ} 53^{\prime}$ to $76^{\circ} 50^{\prime} \mathrm{E}$ longitude and spread over $50,362 \mathrm{~km}^{2}$ which is about $1.6 \%$ of geographical area of the country. It falls in the north Indian part of country. Administratively, the state is divided into 5 divisions, 22 districts, 81 tehsils, 142 developmental blocks, and 12,581 villages.

Bathinda district is situated in southern parts of Punjab state, in the heart of Malwa region. The total area of district is $3353 \mathrm{Km}^{2}$. It is situated between $32.20^{\circ}$ North and $74.95^{\circ}$ East. The total number of villages in district is 281 .

\subsection{Livestock Resource or Livestock Scenario in Punjab}

India is an important agriculture dominated country and the livestock have very important role in Indian farming system. They not only provide milk and meat but also provide farm yard manure, wool, dung etc. India has emerged as the world's largest milk producer and milk production continues to grow at a fairly high rate. Milk production is very important part of the agricultural economy in the state of Punjab.

Dairy farming is an age old subsidiary profession in rural areas of Punjab. It is the second largest milk producing state in India producing $10 \%$ of country's milk production i.e 8 million tonnes annually [3]. Dairy farming is a source of supplementary income for millions of small or marginal farmers and landless labourers in Punjab. Dairying accounts for more than two third of the livestock output and is largely responsible for the rising importance of the livestock sector in the state and country. 


\subsection{Power Scenario in Punjab}

As per the annual plan 2013-14 of Department of Planning, Government of Punjab, the installed capacity in state is $7249 \mathrm{MW}$ and peak demand is $11520 \mathrm{MW}$. The per capita consumption in the state is 1131 $\mathrm{KWH}$ per year with high rising demand and power deficit is $37 \%$. The state government is making an effort to make Punjab self sufficient in power by May 2014 [4]. Punjab is very fast developing state in the present scenario. It has made tremendous progress in all sectors of society. A number of projects are coming in the industrial sector so demand for power will increase in the coming time.

\section{Materials and Methods}

The methodology adopted for conducting the present study is as given below:

\section{$2.1 \quad$ Distribution of Livestock}

The assessment of livestock is done on the basis of the number of different types of animals available in the district under study. The distribution of this livestock has been evaluated in the study area on the basis of recent district wise survey done by Animal Husbandry department of Punjab as $19^{\text {th }}$ Livestock census 2012 [5].

\subsection{Categorization of Livestock}

In this study the categorization of livestock is done into two broad categories the large animals and small animals. The large animals include buffalo, cow, horse, camel, elephant, pony, mules and donkeys. The small animals include sheep, goat, and pig. In this study only those large animals are considered which are having high rate of population and also having large quantity of animal dung or excreta production per day. The quantity of production of excreta of all large and small animals is also identified.

\subsection{Potential of Animal Waste}

The data related to production of animal dung or excreta has been obtained by consulting Animal Husbandry Department, of Govt. of Punjab and from available literature [6]. The average of per day animal dung of per large animal is also determined from literature. The total quantity of animal dung (QAD) in one day is determined from total number of animals $(\mathrm{N})$ and the average value of per day dung of each animal (D).

$$
(Q A D) i=\sum_{i=1}^{n}(N) i X(D) i
$$

The gross potential of animal dung is determined by using residue to product ratio (RPR). The potential of the entire animal dung in each tehsil of district Bathinda has been cumulated on the basis of following model [7]:

$$
(P A D) i=(R P R) i X(Q A D) i
$$

Where PAD is the potential of animal dung of $i^{\text {th }}$ type of animal in ton in one day, RPR of the $i^{\text {th }}$ type of animal and QAD is the total quantity of animal dung of $\mathrm{i}^{\text {th }}$ type in one day.

\subsection{Utilization of Animal Dung for Activities at District level}

The utilization of animal dung at rural areas of district is done for domestic purposes like heating, fertilizer and family type biogas plants. The $8-10 \%$ of the total animal dung in district is used for household activities such as fuel, heating and fertilizer [8]. As per the Central Sector Scheme on National Biogas and Manure Management Programme, which mainly caters to setting up of family type biogas plants, the Punjab Energy Development Agency (PEDA), Punjab has established family type biogas plants in villages of Bathinda district [9].

\subsection{Availability of Surplus Animal Dung for Energy}

The total amount of animal dung cannot be utilized as an energy source, because some amount has already been used for domestic purposes, heating, family type biogas plants and fertilizer in rural areas. The surplus animal dung means that quantity which is not used for any household above said activities and generally available in storage areas in rural parts. The availability of unused or surplus dung for energy is determined by subtracting the current utilization of animal dung from total production of animal dung [7]. This is the actual availability of animal dung that can be supplied for energy generation.

\subsection{Energy from Surplus Animal Dung}

Energy potential from surplus animal dung can be determined by multiplying the net supply potential of surplus animal dung by higher heating value (HHV). Each type of large animal dung has a different HHV. The modification of Bhattacharya model is done for estimating the energy potential [7]: 


$$
Q i=\sum_{i=1}^{n}(S A D i X H H V i) X \eta c
$$

Where $\mathrm{Q}_{\mathrm{i}}$ is energy potential in GJ/year, SAD is surplus animal dung for different types of animals in tonnes/year. HHV is high heating value in GJ/tonnes for air dry dung. $\eta_{c}$ is conversion efficiency. The availability of unused animal dung in each tehsil of Bathinda district is determined for the year 2012-13.

\section{1}

\section{Data Reporting and Results}

Distribution and Categorization of Livestock

The geographical area of Bathinda district is $3401 \mathrm{Km}^{2}$. It has 3 tehsils and 8 blocks. The livestock is scattered or distributed in whole district. The distribution of this livestock has been evaluated in district Bathinda on the basis of recent district wise survey done by Animal Husbandry Department of Punjab as $19^{\text {th }}$ Livestock census 2012 [5], as shown in Table 1.

For the sake of study the categorization of livestock is done into two broad categories the large animals and small animals. Only those large animals are considered for study having high rate of population and also having large quantity of production of animal dung per day. In category of large animals Buffaloes, Cows and Stray Cattles are considered for study.

\section{Punjab State \& District Bathinda -at a glance}

Geographical location of Punjab $29^{\circ} 33^{\prime}$ to $32^{\circ} 32^{\prime} \mathrm{N}$ latitude North

$73^{\circ} 53^{\prime}$ to $76^{\circ} 56^{\prime}$ E longitude East

Land use pattern

Total Geographical Area: $50362 \mathrm{Km}^{2}$

Geographical location of Bathinda $29^{\circ}-33^{\prime}$ to $30^{\circ}-36^{\prime}$ longitudes

$74^{\circ}-38^{\prime}$ to $75^{\circ}-46^{\prime}$ latitudes, Southern part of State

Land use pattern

Administrative Setup

\section{Geographical Area: $\quad 3401 \mathrm{Km}^{2}$}

Tehsils : 3, Blocks: 7, Villages : 281

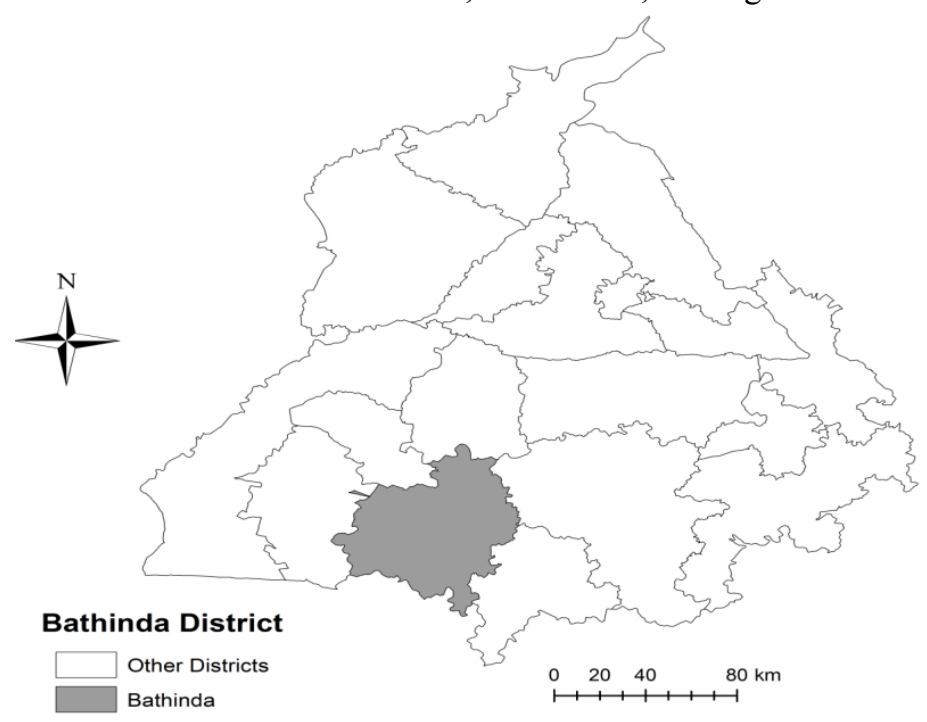

Fig 1- Bathida in Punjab Map

Table 1- Geographical Distribution of Livestock in District Bathinda

\begin{tabular}{|c|c|c|c|c|}
\hline $\begin{array}{l}\text { Livestock } \\
\text { Categories } \\
\end{array}$ & $\begin{array}{l}\text { Tehsil } 1 \\
\text { Bathinda } \\
\end{array}$ & $\begin{array}{l}\text { Tehsil } 2 \\
\text { Rampura Phul }\end{array}$ & $\begin{array}{l}\text { Tehsil } 3 \\
\text { Talwandi Sabo }\end{array}$ & Total \\
\hline Buffaloes & $\begin{array}{l}116717 \\
14461 \mathrm{M} \\
102256 \mathrm{~F} \\
\end{array}$ & $\begin{array}{l}81326 \\
8778 \mathrm{M} \\
72548 \mathrm{~F} \\
\end{array}$ & $\begin{array}{l}76833 \\
9239 \mathrm{M} \\
67594 \mathrm{~F} \\
\end{array}$ & $\begin{array}{l}274876 \\
\text { 32478 Male } \\
\text { 242398 Female }\end{array}$ \\
\hline $\begin{array}{l}\text { Cows E } \\
\text { (Exotic/ Cross } \\
\text { breeds) }\end{array}$ & $\begin{array}{l}52050 \\
9349 \mathrm{M} \\
42701 \mathrm{~F} \\
\end{array}$ & $\begin{array}{l}24333 \\
2634 \mathrm{M} \\
21699 \mathrm{~F} \\
\end{array}$ & $\begin{array}{l}23108 \\
3582 \mathrm{M} \\
19526 \mathrm{~F} \\
\end{array}$ & $\begin{array}{l}99491 \\
15565 \text { Male } \\
83926 \text { Female } \\
\end{array}$ \\
\hline $\begin{array}{l}\text { Cows I } \\
\text { (Indigenous } \\
\text { breeds) }\end{array}$ & $\begin{array}{l}11481 \\
6008 \mathrm{M} \\
5473 \mathrm{~F} \\
\end{array}$ & $\begin{array}{l}11905 \\
6655 \mathrm{M} \\
5250 \mathrm{~F} \\
\end{array}$ & $\begin{array}{l}15431 \\
6678 \mathrm{M} \\
8753 \mathrm{~F} \\
\end{array}$ & $\begin{array}{l}8817 \\
19341 \text { Male } \\
19476 \text { Female } \\
\end{array}$ \\
\hline
\end{tabular}


Estimation of Large Animals Dung for Power Generation - A Case Study of District Bathinda,

\begin{tabular}{|l|l|l|l|l|}
\hline Sheep & 4763 & 938 & 2612 & 8313 \\
& & & & $\begin{array}{l}\text { 2020 Male } \\
6293 \text { Female }\end{array}$ \\
\hline Goats & 19649 & 5459 & 10546 & 35654 \\
& & & $\begin{array}{l}6277 \text { Male } \\
29377 \text { Female }\end{array}$ \\
\hline Pigs & 818 & & & 1113 \\
\hline Horses \& others & 1092 & 191 & 104 & 2217 \\
\hline Camels \& Ass & 80 & 630 & 495 & 282 \\
\hline $\begin{array}{l}\text { Rabbits, Dogs \& } \\
\text { Elephants }\end{array}$ & 13354 & 94 & 108 & 27134 \\
\hline Stray Cattles & 5415 & 8265 & 5515 & 10191 \\
\hline Stray Dogs & 7642 & 1575 & 3201 & 15941 \\
\hline
\end{tabular}

\subsection{Potential of Animal Dung}

The geographical area of Bathinda district is $3401 \mathrm{Km}^{2}$ and it has three tehsils and 281 villages. Dairy farming is a source of supplementary income for millions of small or marginal farmers and landless labourers in villages of Bathinda district of Punjab. Dairying accounts for more than two third of the livestock output and is largely responsible for the rising importance of the livestock sector. The data related to availability of animal dung or excreta has been obtained and calculated as total production of animal dung for one day, month and year. The potential or amount of animal dung at district level was calculated by using appropriate RPR value on dry basis. The RPR value of all animal types under study is calculated experimentally and found that ratio is coming out be in between $16-18 \%$.

Table 2 - Quantity of Animal Dung in One Day

\begin{tabular}{|l|l|l|l|}
\hline $\begin{array}{l}\text { Large Animals } \\
\text { Types } \\
\text { Under study }\end{array}$ & $\begin{array}{l}\text { Daily Average } \\
\text { Excreta or Animal } \\
\text { Dung } \\
\text { per Animal } \\
\text { Wet Weight }(\mathrm{Kg})\end{array}$ & $\begin{array}{l}\text { Large Animal } \\
\text { Population } \\
\text { in Bathinda } \\
\text { District }\end{array}$ & $\begin{array}{l}\text { Total Quantity } \\
\text { of Excreta } \\
\text { or Animal Dung (wet) } \\
\text { per day } \\
(\mathrm{Kg})\end{array}$ \\
\hline Cow E & 11.6 & 99491 & 1154095.6 \\
\hline Cow I & 11.6 & 38817 & 450277.2 \\
\hline Buffaloes & 12.2 & 274876 & 3353487.2 \\
\hline Stray Cattle & 12 & 10191 & 122292 \\
\hline
\end{tabular}

Total Quantity of Animal Dung in one day Total Quantity of Animal Dung in one month Total Quantity of Animal Dung in one year

$$
\begin{aligned}
& =5080152 \mathrm{Kg}=5080.2 \text { tonnes } \\
& =152404560 \mathrm{Kg}=152404.6 \text { tonnes } \\
& =1854255480 \mathrm{Kg}=1854255.5 \text { tonnes }
\end{aligned}
$$

Table 3 - Potential of Animal Dung in One Day

\begin{tabular}{|l|l|l|}
\hline $\begin{array}{l}\text { Large } \\
\text { Animals } \\
\text { Types }\end{array}$ & $\begin{array}{l}\text { Total Quantity } \\
\text { of Excreta } \\
\text { or Animal Dung (wet) } \\
\text { per day ( Kg) }\end{array}$ & $\begin{array}{l}\text { Potential of Animal } \\
\text { Waste per day on dry } \\
\text { basis } \\
(\mathrm{Kg})\end{array}$ \\
\hline Cow E & 1154095.6 & 184655.3 \\
\hline Cow I & 450277.2 & 72044.4 \\
\hline Buffaloes & 3353487.2 & 590213.8 \\
\hline Stray Cattle & 122292 & 20789.7 \\
\hline
\end{tabular}

Potential of animal dung per day

Potential of animal dung per month

Potential of animal dung per year

$$
\begin{aligned}
& =867703.0352 \mathrm{Kg} \quad=867.8 \text { tonnes } \\
& =2631091 \mathrm{Kg}=2631 \text { tonnes } \\
& =316711607.9 \mathrm{Kg} \quad=316711.7 \text { tonnes }
\end{aligned}
$$

\subsection{Utilization of Animal Waste for Activities at District level}

The utilization of animal dung at rural areas of district is done for domestic purposes, heating, fertilizer and family type biogas plants. The availability of surplus amount of animal dung can be calculated by considering the amount of animal dung used at other kind of activities. The $8-10 \%$ of the total animal dung in district is used for household activities such as fuel, heating, fertilizer and family type biogas plants. The PEDA has sanctioned 867 subsidized connections to farmers up to year 2011-2012. The utilization of animal dung for these biogas plants is 218 tonnes per day. The $4 \%$ of the total animal dung per day in Bathinda district is used for running the family type biogas plants.

The availability of surplus animal dung for energy is shown in Table 4 . 
Table 4- Status of Family Type Biogas Plants Established by PEDA in Bathinda District

\begin{tabular}{|l|c|c|}
\hline Year & $\begin{array}{l}\text { No. of Family type } \\
\text { biogas plants }\end{array}$ & $\begin{array}{c}\text { Consumption of Animal dung } \\
\text { or Excreta per day }(\mathrm{Kg})\end{array}$ \\
\hline $2007-2008$ & 151 & 21475 \\
\hline $2008-2009$ & 327 & 48400 \\
\hline $2009-2010$ & 52 & 7950 \\
\hline $2010-2011$ & 332 & 49950 \\
\hline $2011-2012$ & 599 & 9000 \\
\hline
\end{tabular}

Grand Total of Consumption of animal dung per day for

Family Type Biogas Plants

$=217775 \mathrm{Kg}$

$=218$ tonnes

Consumption of animal dung for other local activities on per day basis

$=457213.68 \mathrm{Kg}$

$=457.3$ tonnes

\subsection{Availability of Surplus Animal Dung for Energy}

The availability of surplus animal dung for energy is determined by subtracting the current utilization of animal dung (consumption for family type biogas plants +other activities) from total production of animal dung. This is the actual availability of animal dung that can be supplied for energy potential.

Surplus animal dung for energy potential per day

$$
=4405163.32 \mathrm{Kg}
$$

$=4405.2$ tonnes

\subsection{Potential of Energy from Surplus Animal Dung}

The energy potential of animal dung was estimated for all the types of the large animals under study by using HHV. The average value of HHV is considered for evaluating the energy potential from surplus animal dung. To convert the animal dung into energy, S. Swaran Singh National Institute of Renewable Energy Sources (NIRE), Jalandhar, Punjab has calculated and analyzed the calorific value for the samples of animal dung under study. The average value of HHV for various types of large animals has been reported in Table 6 . The total theoretical energy potential of animal dung was estimated for Bathinda district. This is only the first basis of evaluation, which should be corrected to take into account the efficiency of the conversion process.

Table 5- Average Heating Value of Animal Dung

\begin{tabular}{|l|l|l|l|l|l|}
\hline Animal Types & Animal Excreta & Sub Species & $\begin{array}{l}\text { Average Value of } \\
\text { HHV } \\
\text { (Kcal/ Kg) }\end{array}$ & $\begin{array}{l}\text { Average Value of } \\
\text { HHV } \\
\text { (GJ/Tonne) }\end{array}$ \\
\hline Cow E & Dung & $\begin{array}{l}\text { Adult } \\
\text { Heifer } \\
\text { Calf }\end{array}$ & 3384.1 & 14.2 \\
\hline Cow I & Dung & $\begin{array}{l}\text { Adult } \\
\text { Heifer } \\
\text { Calf }\end{array}$ & 3384.1 & 14.2 \\
\hline Buffaloes & Dung & $\begin{array}{l}\text { Adult } \\
\text { Heifer } \\
\text { Calf }\end{array}$ & 3449.3 & 14.44 \\
\hline Stray Animals & Dung & $\begin{array}{l}\text { Cows } \\
\text { Bulls } \\
\text { Buffaloes }\end{array}$ & 3416.7 & 14.3 \\
\hline
\end{tabular}

Table 6- Surplus Animal Dung in One Day

\begin{tabular}{|l|l|l|}
\hline Animal Types & $\begin{array}{l}\text { Average Value of } \\
\text { HHV } \\
\text { (GJ/ Tonne) }\end{array}$ & $\begin{array}{l}\text { Surplus Animal Dung } \\
\text { (SAD) on dry basis } \\
\text { (tonnes/ day) }\end{array}$ \\
\hline Cow E & 14.2 & 157.7 \\
\hline Cow I & 14.2 & 281.6 \\
\hline Buffaloes & 14.44 & 3016 \\
\hline Stray Animals & 14.3 & 122.3 \\
\hline
\end{tabular}

Surplus animal dung for energy potential per day Surplus animal dung for energy potential per month Surplus animal dung for energy potential per year

The conversion efficiency for estimation of energy potential depends on the process adopted for conversion of energy potential to electric energy. The energy from biogas can be converted to electricity with a typical efficiency of $34-40 \%$ for large turbines and with an efficiency of $25 \%$ for smaller generators. For this 
study a range of turbine efficiency from $25-40 \%$ is used. The average dairy cow produces the equivalent of 80 $\mathrm{kWh}$ per day at $35 \%$ conversion efficiency.

Table 7: Energy Potential from Surplus Animal Dung

\begin{tabular}{|c|c|c|c|}
\hline $\begin{array}{l}\text { Conversion } \\
\text { Efficiency } \\
\eta(\% \text { age })\end{array}$ & $\begin{array}{l}\text { Energy Potential } \\
\text { per Day } \\
\text { (GJ/ day) }\end{array}$ & $\begin{array}{l}\text { Energy Potential } \\
\text { per Month } \\
\text { (GJ/ month) }\end{array}$ & $\begin{array}{l}\text { Energy Potential } \\
\text { per Year } \\
\text { (GJ/ year) }\end{array}$ \\
\hline 25 & 2710.855 & 81325.65 & 989462.075 \\
\hline 35 & 3795.197 & 113855.91 & 1385246.905 \\
\hline 40 & 4337.368 & 130121.04 & 1583139.32 \\
\hline
\end{tabular}

\subsection{Power Generation Potential from Surplus Animal Dung}

To convert the surplus animal dung into power generation potential the appropriate values of all parameters of the recommended model are must. The power generation from surplus animal dung with different conversion efficiencies is shown.

Table 8: Power Generation Potential

\begin{tabular}{|l|l|l|l|}
\hline $\begin{array}{l}\text { Conversion } \\
\text { efficiency } \\
\eta(\% \text { age })\end{array}$ & $\begin{array}{l}\text { Power Generation } \\
\text { Potential } \\
\text { per Day }\end{array}$ & $\begin{array}{l}\text { Power Generation } \\
\text { Potential } \\
\text { per Month } \\
(\mathrm{GWH})\end{array}$ & $\begin{array}{l}\text { Power Generation } \\
\text { Potential } \\
\text { per Year }\end{array}$ \\
\hline 25 & .754 & 22.6 & 274.9 \\
\hline 35 & 1.05 & 31.7 & 384.8 \\
\hline 40 & 1.3 & 36.2 & 439.8 \\
\hline
\end{tabular}

\subsection{Conclusions}

The district Bathinda of Punjab state has a large livestock population and the animal dung of this livestock can be utilized for production of electrical power. A case study has been conducted for estimation of total large animal waste based biomass potential for meeting the growing power demand of the state and also making the state as power surplus state. During study it has been observed that district Bathinda has animal population (large animals) of 423375 and potential of animal dung is 1385247 GJ per year. The electrical energy that can be produced from surplus animal dung with conversion efficiency $35 \%$ is $384.8 \mathrm{GWH}$ per year. The production of electrical energy by use of dung is reducing GHG emission, meeting rising power demand, appropriate use of surplus animal dung and renewable energy production.

\section{References}

[1] Chauhan Suresh. District wise agriculture biomass resource assessment for power generation: A case study from an Indian State, Punjab. Biomass and Bio energy 2012; 37 :205-212.

[2] The Ohio Biomass Energy Program, Public Utilities Commission of Ohio, 180 East Broad Street, Columbus, OH 43215-3793. Turning Manure into Gold: Converting Agricultural Waste to Energy.

[3] ludhiana.nic.in/dept/verka.html, Website of Verka Milk Plant, Ludhiana,Punjab, India

[4] planningcommission.nic.in/plans/stateplan/Presentations13_14/punjab_2013_14.pdf,Annual plan (2013-2014), Planning Commission of India, Government of Punjab, India [ last modified on 30.4 .2013 ].

[5] $19^{\text {th }}$ Livestock Census 2012, Animal Husbandry Department, Punjab, India.

[6] Livestock Census Report 2003, Directorate of Economics and Statistics, Ministry of Agriculture, Government of India.

[7] Singh Jagtar, Panesar B.S, Sharma S.K. Energy potential through agricultural biomass using geographical information system- a case study of Punjab. Biomass and Bioenergy 2007;32:301-307

[8] Fuels from wastes and weeds, Booklet no. 408, Agriculture and Bioenergy ABES-6.

[9] www.peda.gov.in/eng/index.html, Website of Punjab Energy Development Agency (PEDA), Punjab, India

[10] Amanda D Cuéllar, Michael E Webber. Cow power: The energy and emissions benefits of converting manure to biogas. Environ. Res. Lett. 3 (July-September 2008). 